\title{
28 Research Square \\ Lake sediment DNA as a proxy in fish population studies: analytical challenges and opportunities
}

Doreen Yu-Tuan Huang ( $\nabla$ doreen.huang@umu.se)

Umeå University

\section{Richard Bindler}

Umeå University

Christian Bigler

Umeå University

\section{Sofia Ninnes}

Umeå University

Fredrik Olajos

Umeå University

\section{Danny Chun Pong Lau}

Swedish University of Agricultural Sciences

Jonatan Klaminder

Umeå University

Xiao-Ru Wang

Umeå University

\section{Research Article}

Keywords: Lake sediment, fish, sedimentary DNA, environmental DNA (eDNA), metabarcoding, droplet digital PCR (ddPCR)

Posted Date: August 25th, 2021

DOI: https://doi.org/10.21203/rs.3.rs-835560/v1

License: @ (i) This work is licensed under a Creative Commons Attribution 4.0 International License. Read Full License 


\section{Abstract}

Sedimentary environmental DNA (sed-eDNA) coupled with metabarcoding is increasingly exploited for ecological studies, but application of the method to resolve fish dynamics in lakes still needs better validation. This study (1) evaluated the sed-eDNA yields from the commonly used DNeasy PowerSoil DNA Kit from mineral-rich and organic-rich sediments and (2) examined the viability of fish sed-eDNA recovery and detection in surface sediment samples from 13 Swedish mountain lakes, with organic contents of $18-52 \%$, by using conventional PCR and droplet digital PCR. Based on concurrent fish-population surveys these lakes contain arctic char and brown trout. We show that, compared to other specifically designed lysis buffers, the DNeasy PowerSoil DNA Kit is less effective to recover DNA from organic-rich sediments and almost $50 \%$ of the extracted DNA was lost during purification steps. The amplification of fish sed-eDNA using conventional PCR with teleo primers failed to detect positive signals; whereas ddPCR assays enabled quantification of amplifiable DNA in all the extracts. However, further molecular cloning of the positive ddPCR droplets from one sediment sample revealed amplified sequences of unidentified origin that cannot be aligned well to fish. Thus the performance of the teleo primers for quantification of fish sed-eDNA detection requires further examination. For detection of fish sed-eDNA for ecological studies, we suggest that DNA extraction methods and primers should be carefully selected and the performance of ddPCR to detect DNA at low quantities needs to be further scrutinized to circumvent the pitfalls of false positives.

\section{Introduction}

Analysis of the environmental DNA (eDNA) preserved in sediments (sed-eDNA) provides valuable insights for contemporary aquatic surveys ${ }^{1,2}$ and for tracing species dynamics/migration in the past ${ }^{3-6}$. Analysis of sedeDNA can help address issues with taphonomy, because not all organic remains are well preserved, and taxonomy, because not all species can be microscopically identified or resolved to a suitably fine level by morphological analyses ${ }^{7-9}$. However, factors such as the efficiency of DNA adsorption/preservation in different sediment properties ${ }^{10}$ and the recovery rate of eDNA from organic-rich lake sediments ${ }^{11}$ can affect sed-eDNA based inferences. Rigorous validations of eDNA detection methods are necessary to understand the risks of false positive and false negative, and thus warrant robust ecological survey.

An essential step in analyzing sed-eDNA is the successful recovery of the DNA from sediments. DNA extraction with homemade reagents and specific protocols are usually complicated and time-consuming, thus commercial DNA extraction kits have become favorable options. QIAGEN DNeasy PowerSoil and QIAGEN DNeasy PowerMax Kits (former MOBIO PowerSoil and PowerMax Kits) are commonly used for eDNA extractions from sediments. For extracting prokaryotic and eukaryotic eDNA from sediments the efficacy of the PowerSoil Kit, in comparison with other kits and extraction methods, has been well tested ${ }^{11,12}$ and a recent study has demonstrated successful extraction and analysis of ancient fungal DNA from boreal lake sediments with the use of PowerSoil Kit ${ }^{3}$. Although, sed-eDNA of good quality could not be recovered from some samples, particularly those with high organic contents, from boreal lakes ${ }^{13}$ by using the PowerSoil Kit, and the cause remained unclear.

The eDNA metabarcoding has shown great potential to perform fish community surveys and monitoring ${ }^{14,15}$, but discrepancies in the detected community richness between eDNA metabarcoding and field surveys have 
been reported, which suggest that metabarcoding is not yet a quantitative approach for freshwater ecology studies $^{16,17}$. Moreover, eDNA in water column does not always capture the fish species in lakes ${ }^{18}$ and PCR inhibitors in sed-eDNA can lead to negative detection of fish DNA in some environmental samples ${ }^{4}$. The recent development of droplet digital PCR (ddPCR) allows partitioning of the PCR mix into thousands of nanoliter droplets, which mitigates PCR inhibition and offers better detection and quantification of eDNA in environmental samples compared to conventional and quantitative PCR (qPCR) ${ }^{19-21}$. To successfully apply this new technique in ecological survey, careful validation of the method is needed to ascertain that the real target DNA is captured and reflected, but so far its application on eDNA detection has not yet been carefully scrutinized.

This study aims to examine the viability of fish DNA recovery from boreal lake sediments in Sweden for fish population surveys. Our objectives were to (1) evaluate the total DNA yield of the PowerSoil Kit from sediments with varied organic contents in comparison to other home-made reagents, and (2) examine the possibility of quantifying fish DNA from boreal/alpine lake sediments which have organic matter contents (measured as loss-on-ignition) up to $52 \%$. We analyzed surface sediments, from both shallow and deep sites, from 13 subalpine and alpine lakes from two nearby areas in the western Swedish mountains. The lakes differ in fish abundance, morphometry, water chemistry and sediment geochemistry. Considering the potential for DNA degradation in sediments, we selected a commonly used fish DNA metabarcode, teleo primers ${ }^{14}$, which amplifies a 64 bp fragment in the 12S mitochondrial DNA. We compared the DNA detection by conventional PCR and ddPCR approaches. Our results illustrate potential challenges and opportunities in DNA metabarcoding for environmental survey.

\section{Materials And Methods}

\subsection{Study sites and sampling}

The 13 sub-alpine and alpine lakes in our study are located in Jämtland in western Sweden (Fig. 1), including 4 lakes in Edsåsdalen (63.3 $\mathrm{N}$ and $\left.12.9^{\circ} \mathrm{E}\right)$ and 9 lakes in Skalstugan $\left(63.5-63.7^{\circ} \mathrm{N}\right.$ and $\left.12.1-12.2^{\circ} \mathrm{E}\right)$. The lakes in Edsåsdalen are at or above present-day treeline, whereas the lakes in Skalstugan are at or below treeline. Intensive field surveys were conducted during June-September 2017, which included lake morphology, gill-net fishing, and water and surface sediment sampling. The current fish species in the lakes are Arctic char (Salvelinus alpinus) and/or Brown trout (Salmo trutta) (Table 1). The relative abundance of fish is measured as catch per unit of effort [CPUE, expressed as gram per net; see Capo et al. ${ }^{22}$ for detailed description of the fish sampling]. 
Table 1

Lake properties, water chemistry, and fish abundance in the 13 study lakes in Jämtland. All the water chemistry data was presented as mean \pm SD.

\begin{tabular}{|c|c|c|c|c|c|c|c|c|c|c|c|}
\hline \multirow[t]{2}{*}{ Lake } & Area & Depth & $\mathrm{pH}$ & DOC & $\begin{array}{l}\mathrm{NO}_{3}^{-} \\
\mathrm{N}\end{array}$ & $\begin{array}{l}\mathrm{NH}_{4-}^{-} \\
\mathrm{N}\end{array}$ & $\begin{array}{l}\mathrm{PO}_{4-}^{-} \\
\mathrm{P}\end{array}$ & $\mathrm{TN}$ & $\mathrm{TP}$ & $\begin{array}{l}\text { Fish } \\
\text { CPUE }\end{array}$ & \multirow[t]{2}{*}{$\begin{array}{l}\text { Current } \\
\text { fish } \\
\text { species }\end{array}$} \\
\hline & ha & $\mathrm{m}$ & & $\mathrm{mg} / \mathrm{L}$ & $\mu \mathrm{g} / \mathrm{L}$ & $\mu \mathrm{g} / \mathrm{L}$ & $\mu g / L$ & $\mu g / L$ & $\mu g / L$ & g/net & \\
\hline ZF08 & 4.8 & 14 & 6.40 & $\begin{array}{l}3.98 \\
\pm \\
0.22\end{array}$ & $\begin{array}{l}5.20 \\
\pm 1.63\end{array}$ & $\begin{array}{l}7.88 \\
\pm \\
1.65\end{array}$ & $\begin{array}{l}0.97 \\
\pm \\
1.09\end{array}$ & $\begin{array}{l}154.3 \\
\pm 55.3\end{array}$ & $\begin{array}{l}4.2 \\
\pm 0.9\end{array}$ & 440.8 & $\begin{array}{l}\text { S. alpinus, } \\
\text { S. trutta }\end{array}$ \\
\hline ZF09 & 2.7 & 8 & 6.00 & $\begin{array}{l}4.51 \\
\pm \\
0.49\end{array}$ & $\begin{array}{l}2.80 \\
\pm 1.38\end{array}$ & $\begin{array}{l}6.28 \\
\pm \\
1.20\end{array}$ & $\begin{array}{l}0.90 \\
\pm \\
0.48\end{array}$ & $\begin{array}{l}162.6 \\
\pm 42.4\end{array}$ & $\begin{array}{l}4.0 \\
\pm 0.9\end{array}$ & 305.4 & S. trutta \\
\hline ZF10 & 10.2 & 23 & 6.30 & $\begin{array}{l}2.05 \\
\pm \\
0.13\end{array}$ & $\begin{array}{l}13.15 \\
\pm 5.98\end{array}$ & $\begin{array}{l}6.38 \\
\pm \\
1.32\end{array}$ & $\begin{array}{l}0.51 \\
\pm \\
0.48\end{array}$ & $\begin{array}{r}146.5 \\
\pm 70.5\end{array}$ & $\begin{array}{l}4.1 \\
\pm 1.0\end{array}$ & 300.3 & $\begin{array}{l}\text { S. alpinus, } \\
\text { S. trutta }\end{array}$ \\
\hline ZF11 & 3.9 & 14 & 6.27 & $\begin{array}{l}6.23 \\
\pm \\
1.10\end{array}$ & $\begin{array}{l}3.85 \\
\pm 1.30\end{array}$ & $\begin{array}{l}9.38 \\
\pm \\
3.27\end{array}$ & $\begin{array}{l}0.73 \\
\pm \\
0.38\end{array}$ & $\begin{array}{r}190.2 \\
\pm 21.8\end{array}$ & $\begin{array}{l}4.3 \\
\pm 0.3\end{array}$ & 1171.5 & $\begin{array}{l}\text { S. alpinus, } \\
\text { S. trutta }\end{array}$ \\
\hline ZF12 & 3 & 9 & 6.13 & $\begin{array}{l}5.10 \\
\pm \\
1.43\end{array}$ & $\begin{array}{l}2.60 \\
\pm 0.72\end{array}$ & $\begin{array}{l}7.82 \\
\pm \\
0.93\end{array}$ & $\begin{array}{l}0.62 \\
\pm \\
0.30\end{array}$ & $\begin{array}{r}165.0 \\
\pm 43.9\end{array}$ & $\begin{array}{l}3.9 \\
\pm 0.3\end{array}$ & 749.5 & $\begin{array}{l}\text { S. alpinus, } \\
\text { S. trutta }\end{array}$ \\
\hline ZF13 & 3.7 & 9 & 6.03 & $\begin{array}{l}7.52 \\
\pm \\
1.08\end{array}$ & $\begin{array}{l}5.24 \\
\pm 1.34\end{array}$ & $\begin{array}{l}7.16 \\
\pm \\
0.69\end{array}$ & $\begin{array}{l}1.20 \\
\pm \\
0.29\end{array}$ & $\begin{array}{l}188.4 \\
\pm 22.7\end{array}$ & $\begin{array}{l}4.8 \\
\pm 0.6\end{array}$ & 394.9 & S. trutta \\
\hline ZF14 & 2.7 & 8 & 5.76 & $\begin{array}{l}4.90 \\
\pm \\
1.23\end{array}$ & $\begin{array}{l}2.09 \\
\pm 0.97\end{array}$ & $\begin{array}{l}7.25 \\
\pm \\
0.77\end{array}$ & $\begin{array}{l}0.73 \\
\pm \\
0.52\end{array}$ & $\begin{array}{l}183.1 \\
\pm 37.0\end{array}$ & $\begin{array}{l}3.8 \\
\pm 0.4\end{array}$ & 335.8 & S. trutta \\
\hline ZF15 & 1.3 & 3.5 & 6.04 & $\begin{array}{l}7.13 \\
\pm \\
1.63\end{array}$ & $\begin{array}{l}2.76 \\
\pm 0.81\end{array}$ & $\begin{array}{l}7.19 \\
\pm \\
0.74\end{array}$ & $\begin{array}{l}0.65 \\
\pm \\
0.06\end{array}$ & $\begin{array}{r}199.3 \\
\pm 27.9\end{array}$ & $\begin{array}{l}5.3 \\
\pm 1.2\end{array}$ & 550.4 & S. trutta \\
\hline ZF16 & 1.8 & 4.5 & 6.11 & $\begin{array}{l}7.50 \\
\pm \\
1.25\end{array}$ & $\begin{array}{l}2.85 \\
\pm 0.29\end{array}$ & $\begin{array}{l}7.55 \\
\pm \\
0.78\end{array}$ & $\begin{array}{l}1.33 \\
\pm \\
0.41\end{array}$ & $\begin{array}{r}193.9 \\
\pm 45.1\end{array}$ & $\begin{array}{l}5.0 \\
\pm 0.7\end{array}$ & 518.4 & S. trutta \\
\hline ZF17 & 2.5 & 8 & 5.93 & $\begin{array}{l}4.76 \\
\pm \\
0.14\end{array}$ & $\begin{array}{l}1.36 \\
\pm 0.53\end{array}$ & $\begin{array}{l}5.73 \\
\pm \\
1.27\end{array}$ & $\begin{array}{l}1.33 \\
\pm \\
0.53\end{array}$ & $\begin{array}{r}163.6 \\
\pm 18.8\end{array}$ & $\begin{array}{l}4.4 \\
\pm 0.7\end{array}$ & $-*$ & $\begin{array}{l}\text { S. alpinus, } \\
\text { P. } \\
\text { phoxinus }\end{array}$ \\
\hline ZF19 & 5.7 & 14 & 6.16 & $\begin{array}{l}4.48 \\
\pm \\
0.26\end{array}$ & $\begin{array}{l}3.46 \\
\pm 3.36\end{array}$ & $\begin{array}{l}4.98 \\
\pm \\
2.43\end{array}$ & $\begin{array}{l}0.58 \\
\pm \\
0.09\end{array}$ & $\begin{array}{l}136.0 \\
\pm 46.9\end{array}$ & $\begin{array}{l}4.5 \\
\pm 0.3\end{array}$ & 506.6 & S. alpinus \\
\hline ZF20 & 2.7 & 7 & 6.05 & $\begin{array}{l}3.23 \\
\pm \\
0.22\end{array}$ & $\begin{array}{l}0.73 \\
\pm 0.47\end{array}$ & $\begin{array}{l}4.67 \\
\pm \\
1.02\end{array}$ & $\begin{array}{l}1.07 \\
\pm \\
0.35\end{array}$ & $\begin{array}{l}152.0 \\
\pm 59.0\end{array}$ & $\begin{array}{l}4.0 \\
\pm 0.9\end{array}$ & 2113.4 & S. alpinus \\
\hline
\end{tabular}

--*: only one S. alpinus (1603.35g) was caught over 9 nets.

†: Phoxinus phoxinus. 


\begin{tabular}{|c|c|c|c|c|c|c|c|c|c|c|c|}
\hline \multirow[t]{2}{*}{ Lake } & Area & Depth & $\mathrm{pH}$ & DOC & $\begin{array}{l}\mathrm{NO}_{3}^{-} \\
\mathrm{N}\end{array}$ & $\begin{array}{l}\mathrm{NH}_{4^{-}} \\
\mathrm{N}\end{array}$ & $\begin{array}{l}\mathrm{PO}_{4^{-}} \\
\mathrm{P}\end{array}$ & TN & TP & $\begin{array}{l}\text { Fish } \\
\text { CPUE }\end{array}$ & \multirow[t]{2}{*}{$\begin{array}{l}\text { Current } \\
\text { fish } \\
\text { species }\end{array}$} \\
\hline & ha & m & & $\mathrm{mg} / \mathrm{L}$ & $\mu g / L$ & $\mu g / L$ & $\mu g / L$ & $\mu g / L$ & $\mu g / L$ & g/net & \\
\hline ZF21 & 3.8 & 12 & 5.99 & $\begin{array}{l}2.73 \\
\pm \\
0.08\end{array}$ & $\begin{array}{l}2.94 \\
\pm 0.50\end{array}$ & $\begin{array}{l}7.31 \\
\pm \\
2.60\end{array}$ & $\begin{array}{l}1.02 \\
\pm \\
0.21\end{array}$ & $\begin{array}{l}171.9 \\
\pm 66.0\end{array}$ & $\begin{array}{l}5.1 \\
\pm 1.6\end{array}$ & 312.8 & S. trutta \\
\hline \multicolumn{12}{|c|}{-*: only one $S$. alpinus $(1603.35 \mathrm{~g})$ was caught over 9 nets. } \\
\hline
\end{tabular}

Surface sediments were collected from the deepest basin in all 13 lakes, and for 11 lakes also a shallow site close to shore to assess potential spatial variations in fish DNA due to different preferred habitats (i.e., 24 core sites in total). For each site, we collected the uppermost $1-2 \mathrm{~cm}$ of undisturbed sediment from three sediment cores that were transferred immediately into DNA-free Falcon tubes. The triplicate surface sediment samples from each core site were treated individually for the DNA analyses, i.e., 72 samples in total. Sample tubes were cleaned with $10 \%$ bleach prior to entering a dedicated ancient DNA lab at Umeå University and were stored at $-20^{\circ} \mathrm{C}$ until DNA analysis.

\subsection{Water chemistry and sediment geochemistry}

Water samples were collected on several occasions during the survey period, and consisted of integrated samples collected from several depths. The samples for dissolved organic carbon (DOC) analysis were acidified in the field with $500 \mu \mathrm{L} 1.2 \mathrm{M} \mathrm{HCl}$. In the lab, water samples were filtered through $0.45 \mu \mathrm{m}$ filters before analysis of nitrate $\left(\mathrm{NO}_{3}-\mathrm{N}\right)$, ammonium $\left(\mathrm{NH}_{4}{ }^{+}-\mathrm{N}\right)$, phosphate $\left(\mathrm{PO}_{4}{ }^{2}-\mathrm{P}\right)$ and dissolved organic carbon (DOC). Lake-water DOC was analyzed using an infrared gas analyzer, Formacs $\mathrm{HT}$-I (Skalar). Dissolved nutrients $\left(\mathrm{NO}_{3}{ }^{-}\right.$ $\mathrm{N}, \mathrm{NH}_{4}{ }^{+}-\mathrm{N}, \mathrm{PO}_{4}{ }^{2}-\mathrm{P}$ ) were analyzed using a spectrophotometer with a segmented flow analyzer, according to methods in MT3B (QuAAtro Multi-test Methods): for nitrate, method Q-035-04 using a copperized Cd reduction coil to form an azo dye; for ammonia, salicylate method Q-033-04; and for phosphate, molybdenum blue method Q-037-05. For total phosphorus (TP) analysis, filtered samples were passed through an online digestion step, alkaline acidic persulfate method, at $110^{\circ} \mathrm{C}$ and $0.9 \mathrm{MPa}$ and then analyzed using a QuAAtro 39 (Seal Analytical). Total nitrogen (TN) was analyzed on an ND25 unit connected to the Fomacs using a chemiluminescent detector. We also include data (winter data) of lake-water TN and TP analyzed earlier in the same year by the County Administrative Board of Jämtland in order to obtain annual lake nutrient information.

Surface sediments were freeze-dried prior to geochemical analysis. Organic content was estimated via loss on ignition (LOI) at $550^{\circ} \mathrm{C}$, and total concentrations of major and trace elements were measured on $200 \mathrm{mg}$ sediment samples by wavelength dispersive X-ray fluorescence spectrometry (XRF) using a Bruker S8 Tiger spectrometer [see full method description in Rydberg ${ }^{23}$ ]. Principal component analysis (PCA) was used for the characterizing the sediment properties. Prior to PCA, data that was not normally distributed was logtransformed.

\subsection{Test of sed-eDNA yields from DNeasy PowerSoil DNA Kit}


To test the efficacy of the PowerSoil Kit to extract sufficient sed-eDNA, we measured the quantities of extracted DNA from the PowerSoil Kit in comparison to the three lysis buffers. To assess potential differences in DNA extraction due to varying organic matter content, we used three samples previously collected from other sites that had very different organic matter contents (measured as LOI), ranging from low (<5\%), medium (ca. 30\%) to high (ca. 60\%). Lysis buffers and their ingredients used for this test were: Buffer 1 contained $1 \%$ sodium dodecyl sulfate (SDS), 100mM Tris-HCl, 200 mM EDTA, and 500 mM Na $2 \mathrm{HPO}_{4}$ (pH 8.6) ${ }^{24}$; Buffer 2 contained 4\% SDS, $100 \mathrm{mM}$ Tris- $\mathrm{HCl}, 200 \mathrm{mM}$ EDTA, and $500 \mathrm{mM} \mathrm{Na}_{2} \mathrm{HPO}_{4}$; Buffer 3 contained $30 \mathrm{mM}$ Tris- $\mathrm{HCl}, 30 \mathrm{mM}$ EDTA, $800 \mathrm{mM}$ quanidium hydrochloride, and 0.5\% Triton X-100 ${ }^{11}$; and the Buffer from the PowerSoil Kit, which was the $\mathrm{C} 1$ solution (lysis buffer) with the buffer in bead tubes. Each sediment was subjected to a quick centrifuge to remove most of the pore water. For each sediment type, three replicate subsamples of $0.5 \mathrm{~g}$ wet sediment were mixed with each of the four buffers for DNA extraction. For buffers 1,2 and 3, subsamples were mixed with $500 \mu \mathrm{L}$ buffer solution. The mixtures were incubated at $70^{\circ} \mathrm{C}$ for 30 min with interval vortex, and the supernatant collected after 2 min centrifuge at $13000 \mathrm{rpm}$. The DNA in the supernatant was mixed with an equal volume of $20 \%$ PEG8000/2.5M NaCl for DNA precipitation and concentration, and the DNA was finally resuspended in $50 \mu \mathrm{L}$ TE buffer for quantification. The quantities of extracted DNA were evaluated by Qubit with a dsDNA HS Assay Kit. Two-way ANOVA was used to test the effects of DNA lysis buffers on DNA yields from sediments with varied LOI, by using the software MedCalc.

The extracted DNA from the PowerSoil Kit was subsequently purified with the kit and the final DNA recovery after purification was analyzed in order to quantify the DNA loss during purification. We subsequently tested the amplifiability of the extracted DNA. Due to the fact that the teleo primers were not used and tested on sedeDNA previously and thus the performance remained uncertain, we selected the widely used and reliable trnL c and $\mathrm{h}$ primers for plant sed-eDNA amplification ${ }^{24}$ in conventional PCR as described in the Sect. 2.5.

\subsection{DNA extraction from lake sediment for fish DNA metabarcoding}

DNA isolation from sediments were performed in a dedicated ancient DNA lab at Umeå University that is isolated from other labs and has a positive air pressure system accompanied by HEPA air filter system. Before extraction, samples were placed in a $4^{\circ} \mathrm{C}$ fridge for 1 hour for sediment precipitation followed by water removal by pipetting and homogenization by mixing, because eDNA is adsorbed on sediment but not in pore water ${ }^{6}$. Each sediment was extracted once. Because the precipitated sediments remained high in moisture content, we used $0.5 \mathrm{~g}$ of sediment for DNA extraction in order to increase the volume of actual sediment and the likelihood of fish DNA recovery. From each sample, approximately $0.5 \mathrm{~g}$ of condensed sediment was processed using the PowerSoil Kit by following the manufacturer's protocol with a modification that the samples were incubated overnight on a shaker at $60^{\circ} \mathrm{C}$ for the lysis step (after adding $\mathrm{C} 1$ buffer). Together with the samples, each extraction batch included one extraction blank to assess lab contamination and cross contamination between samples during extraction. In total, 6 extraction blanks and 72 sediment extracts were prepared.

\subsection{DNA amplification and sequencing}

We used two PCR methods, conventional PCR and digital droplet PCR (ddPCR), with a pair of general fish DNA metabarcodes - teleo_F and teleo_R primers ${ }^{14}$, to determine the presence of amplifiable fish DNA in the sediment extracts. These teleo primers were designed based on mitochondrial 12S gene of 64 European 
freshwater fish species and the resulting reference database tested on water samples from 62 sites corresponding to a wide range of aquatic ecosystems ${ }^{14}$. Moreover, Valentini et al. ${ }^{14}$ and primer BLAST against GenBank both suggested that the teleo primers amplify $S$. alpinus and $S$. trutta (expected amplicon of approx. $100 \mathrm{bp}$ including primers), which are found in our Swedish lakes, but no other non-fish taxa, and therefore, these teleo primers were selected for this study. To avoid contamination, PCR preparations for both conventional PCR and ddPCR were done in the ancient DNA lab.

PCRs were set up in $25 \mu \mathrm{L}$ reaction containing $1.25 \mathrm{U}$ of HotStartTaq DNA polymerase (QIAGEN), 1X PCR buffer, 2 mM Mg2 ${ }^{+}, 0.2 \mathrm{mM}$ dNTPs, $4 \mu \mathrm{g}$ of Bovine Serum Albumin (BSA), $0.4 \mu \mathrm{M}$ teleo_F and teleo_R primers, and $2 \mu \mathrm{L}$ DNA isolate. Each PCR batch had at least one PCR negative control (no DNA template) and one PCR positive control (extracted Salvelinus alpinus DNA) to assess PCR performance. The prepared PCR mixtures were brought to a PCR lab for amplification under the condition of denaturation for $15 \mathrm{~min}$ at $95^{\circ} \mathrm{C}$, followed by 35 cycles of $30 \mathrm{~s}$ at $94^{\circ} \mathrm{C}, 30 \mathrm{~s}$ at $56^{\circ} \mathrm{C}$, and $1 \mathrm{~min}$ at $72^{\circ} \mathrm{C}$, and then a final elongation for $7 \mathrm{~min}$ at $72^{\circ} \mathrm{C}$.

The ddPCR assays were performed using QX200'" ddPCR ${ }^{m ! \prime}$ EvaGreen Supermix (Bio-Rad, CA, USA), following the manufacturer's instructions, and the details are provided in Supplementary Materials. Each ddPCR reaction contains 1x ddPCR EvaGreen Supermix, $0.2 \mu \mathrm{M}$ teleo_F and teleo_R primers, and DNA isolate of $3 \mu \mathrm{L}$ in $20 \mu \mathrm{L}$ reaction. The PCR program for the ddPCR assay was: denature at $95^{\circ} \mathrm{C}$ for $5 \mathrm{~min}$, followed by 35 cycles of $30 \mathrm{~s}$ at $95^{\circ} \mathrm{C}$ and $1 \mathrm{~min}$ at $56^{\circ} \mathrm{C}$ with ramp rate of $2^{\circ} \mathrm{C}$ per sec (note that ddPCR with EvaGreen Supermix does not require elongation process), and finally $5 \mathrm{~min}$ at $4^{\circ} \mathrm{C}$ and $5 \mathrm{~min}$ at $90^{\circ} \mathrm{C}$ for signal stabilization and then hold at $4^{\circ} \mathrm{C}$. We ran triplicate PCR reactions for each DNA extract. The PCR plate was then scanned by the QX200 Droplet Reader (Bio-Rad) to read fluorescence from each droplet, and the Bio-Rad QuantaSoft software version 1.7.4 was used to calculate target DNA concentration. The PCR triplicates were averaged and the final DNA count was shown as number of copies per $\mu \mathrm{L}$ in a PCR reaction.

For the proof of concept, we collected the amplified ddPCR droplets from one sample, which had the highest number of positive droplets, for cloning and DNA sequencing to verify the amplicon sequences. The droplets from transferred to a $1.5 \mathrm{~mL}$ tube with $20 \mu \mathrm{L}$ of TE (Tris-EDTA) buffer and $70 \mu \mathrm{L}$ of chloroform, and the sample was mixed for $1 \mathrm{~min}$. After centrifuge at 13,000 rpm for $10 \mathrm{~min}$, the upper aqueous phase containing purified amplicon DNA was cloned using CloneJet PCR Kit (ThermoScientific) at the Protein Expertise Platform at Umeå University. Twenty colonies were picked and sequenced at Eurofins. DNA sequences were analyzed using Geneious Prime@ 2021.0.3 version.

\section{Results}

\subsection{Fish abundance, water chemistry and sediment geochemistry}

The estimated abundance of fish varied substantially among lakes; the CPUE ranged from 305 to $2000 \mathrm{~g} / \mathrm{net}$. The lowest number of fish caught was one individual of S. alpinus caught over 9 nets in lake ZF17.

The DOC and TN concentrations and other water chemistry data are shown in Table 1. The DOC concentrations in the lakes range from 2.7 to $7.5 \mathrm{mg} / \mathrm{L}$ and TN from 136 to $200 \mu \mathrm{g} / \mathrm{L}$. No significant nutrient 
differences were observed between lakes positioned above or below current treeline.

Principal component analysis of surface sediment geochemistry shows that sediment composition varies substantially both between lakes and between deep and shallow sites within the same lake (Fig. 2, Table S1). Samples that load positively on the first component (PC1) are characterized by redox sensitive elements, e.g., $\mathrm{Fe}, \mathrm{Mn}$, and $\mathrm{Zn}$, and are predominantly shallow sites. Samples on the negative side of PC1 are instead characterized by elements typically found in silicate minerals, including $\mathrm{Al}, \mathrm{K}, \mathrm{Mg}, \mathrm{Na}, \mathrm{Ti}, \mathrm{Zr}$ and in part $\mathrm{Si}$. The second component (PC2) captures the organic content in the samples, as indicated by positive loadings for LOI and elements associated with organic matter, including $\mathrm{Br}, \mathrm{Ca}, \mathrm{Cl}, \mathrm{P}, \mathrm{Pb}$, and $\mathrm{S}$, with mostly deeper sites loading on the positive side of this component. All surface sediment samples have relatively high organic matter contents, with LOI ranging from 18 to $52 \%$. Silicon - recalculated as $\mathrm{SiO}_{2}$ - ranges from 8 to $47 \%$, and may in some lakes therefore be of equal importance to organic matter. Silicon is in part related to the silicate minerals on $\mathrm{PC} 1$, but loads primarily on $\mathrm{PC} 3$, indicating the primary source is biogenic (diatoms) rather than minerogenic, which often is the case in northern Swedish lakes ${ }^{25}$. A full sample list, sampling depths and geochemistry data can be found Table S1.

\subsection{Sedimentary DNA extraction efficiency using DNeasy PowerSoil DNA Kit}

Results of the two-way ANOVA and Tukey HSD post-hoc test indicated that the efficiency of DNeasy PowerSoil DNA Kit and other homemade buffers (except Buffer 3) significantly differed on mineral-rich and organic-rich sediments $(p=0.001)$ (Fig. 3 and Table S2). Compared to other homemade buffers, the lysis buffer from the PowerSoil Kit had a slightly better DNA extraction efficiency for the test sediment with very low organic content $(<5 \%)$ than for test sediments with higher organic content (>30\%) (Fig. 3) $(p<0.05)$. The increase of SDS from $1-4 \%$ in the homemade lysis buffer did not substantially increase DNA quantity, given that there was no significant different $(p=0.773)$ in DNA yield from Buffers 1 and 2. We did not detect any DNA using Buffer 3, which might be due to poor DNA extraction or poor DNA precipitation while using PEG8000/ $\mathrm{NaCl}$.

In general, the lysis buffer from the PowerSoil Kit had good DNA yields (> $1000 \mathrm{ng}$ from sediments of $0.5 \mathrm{~g}$ ) from all three tested sediments, but there was a significant DNA loss ( $>45 \%)$ during the purification steps of the PowerSoil Kit (Table 2). Nevertheless, the extracted DNA from all tested sediments were clean and amplifiable as the vascular plant DNA (approx. $200 \mathrm{bp} t r n \mathrm{~L}$ ) was amplified (Table 2). 
Table 2

DNA yields from different sediment types before and after the application of PowerSoil Kit purification steps and DNA amplifiability of the extracts. Sediments of $0.5 \mathrm{~g}$ were used for DNA extraction and purification. All the quantified DNA yields are presented as mean \pm SD.

\begin{tabular}{|c|c|c|c|c|c|}
\hline Sediment types & $\begin{array}{l}\text { Extracted DNA } \\
\text { before purification } \\
\text { (ng) }\end{array}$ & $\begin{array}{l}\text { DNA used for } \\
\text { purification (ng) }\end{array}$ & $\begin{array}{l}\text { DNA after } \\
\text { purification } \\
\text { (ng) }\end{array}$ & $\begin{array}{l}\text { DNA } \\
\text { loss } \\
(\%)\end{array}$ & $\begin{array}{l}\text { Amplification } \\
\text { of trmL gene* }\end{array}$ \\
\hline $\begin{array}{l}\text { Mineral-rich } \\
(<5 \% \text { LOI) }\end{array}$ & $2586.7 \pm 660.5$ & 1410 & $\begin{array}{l}746.7 \pm \\
156.5\end{array}$ & $\begin{array}{l}47.0 \pm \\
11.1\end{array}$ & Yes \\
\hline $\begin{array}{l}\text { Medium organic- } \\
\text { rich (ca. } 30 \% \text { LOI) }\end{array}$ & $1310.0 \pm 18.0$ & 714 & $\begin{array}{l}364.6 \pm \\
50.0\end{array}$ & $\begin{array}{l}48.9 \pm \\
7.0\end{array}$ & Yes \\
\hline $\begin{array}{l}\text { High organic-rich } \\
\text { (ca.60\% LOI) }\end{array}$ & $1155.0 \pm 296.8$ & 630 & $\begin{array}{l}346.7 \pm \\
18.6\end{array}$ & $\begin{array}{l}45.0 \pm \\
2.9\end{array}$ & Yes \\
\hline
\end{tabular}

*Non-diluted extracts were used for the amplification of approx. 200 bp trnL gene.

\subsection{Sedimentary fish DNA detection by conventional PCR and ddPCR assays}

The conventional PCRs with teleo primers yielded unsuccessful or poor DNA amplification (Table 3), i.e., no visible DNA band via gel electrophoresis on PCR products with the non-diluted extracts. Successful PCRs were observed in two samples (ZF09 and ZF19-2) when the extracts were diluted 100-fold (Table 3), and the amplicon size was ca. 200 bp. The fish DNA metabarcoding via PCR was unviable, which can be ascribed to either PCR inhibition or a lack of sufficient fish DNA in the surface sediment extracts. Similarly, the preliminary ddPCR trials (Fig. S1) showed substantial noise (exemplified by the numerous grey dots between 5000-10000 RFU in Fig. S1) and poor DNA amplification with non-diluted or 10-fold diluted DNA extracts due to severe PCR inhibitions. To allow better fish DNA amplification and quantification with less interference from inhibition (i.e., fewer grey dots in ddPCR assays), we found that the DNA extracts required at least 100-fold dilution (Fig. S1). However, 1000-fold dilution possessed the risk of overestimating the positive signals because the number of copies (red text in Fig. S1) became higher than the reads from 100-fold dilution. Thus, we performed the final fish DNA quantification with ddPCR using 100-fold diluted sediment extracts. The counted DNA copies in extracts from all of the surface sediments are listed in Table 3 and Table S3. There was no remarkable amplification from the extraction controls in either the qPCR or ddPCR assays (Table S3). 
Table 3

Fish DNA detections/counts in sediment extracts with teleo primers analyzed by conventional PCR and ddPCR. The ddPCR DNA counts are presented as mean \pm SD.

\begin{tabular}{|c|c|c|c|}
\hline \multirow[t]{2}{*}{ ID } & \multirow[t]{2}{*}{ Depth (m) } & \multirow{2}{*}{$\begin{array}{l}\text { Conv. PCR }{ }_{\text {Fish }} \text { DNA } \\
\text { Amplicon on gel }\end{array}$} & \multirow{2}{*}{$\begin{array}{l}\text { ddPCR }_{\text {Fish }} \text { DNA } \\
\text { Copies/ } \mu \mathrm{L}\end{array}$} \\
\hline & & & \\
\hline ZF08-1 & 14 & No & $567 \pm 467$ \\
\hline ZF08-2 & 4 & No & $0 \pm 0$ \\
\hline ZF09 & 8 & Yes* & $997 \pm 326$ \\
\hline ZF10-1 & 23 & No & $43 \pm 31$ \\
\hline ZF10-2 & 7.5 & No & $107 \pm 120$ \\
\hline ZF11-1 & 14 & No & $43 \pm 12$ \\
\hline ZF11-2 & 4 & No & $5 \pm 9$ \\
\hline ZF12-1 & 9 & No & $148 \pm 142$ \\
\hline ZF12-2 & 4 & No & $276 \pm 400$ \\
\hline ZF13-1 & 9 & No & $66 \pm 29$ \\
\hline ZF13-2 & 3 & No & $10 \pm 18$ \\
\hline ZF14-1 & 8 & No & $20 \pm 18$ \\
\hline ZF14-2 & 2 & No & $164 \pm 107$ \\
\hline ZF15-1 & 3.5 & No & $5 \pm 9$ \\
\hline ZF15-2 & 2.5 & No & $181 \pm 52$ \\
\hline ZF16-1 & 4.5 & No & $217 \pm 234$ \\
\hline ZF16-2 & 3 & No & $156 \pm 119$ \\
\hline ZF17-1 & 8 & No & $756 \pm 451$ \\
\hline ZF17-2 & 3 & No & $87 \pm 31$ \\
\hline ZF19-1 & 6 & No & $125 \pm 97$ \\
\hline ZF19-2 & 14 & Yes* & $5086 \pm 2459$ \\
\hline ZF20-1 & 7 & No & $731 \pm 330$ \\
\hline ZF20-2 & 2.8 & No & $64 \pm 65$ \\
\hline ZF21 & 12 & No & $38 \pm 15$ \\
\hline
\end{tabular}


Nineteen sequences were successfully recovered from the cloning from sample ZF19-2 (Table 4). We observed no mismatches on the forward primer loci, and 4 out of 17 sequences had at least one mismatch or gap on the reverse primer loci. The sequences were between 145 and 204 bp (including primers), which were much longer than the expected length (ca. 100 bp including primers) for $S$. trutta and $S$. alpinus (Table 4). The sequence alignment showed there were two main templates with one being 145 bp and the other mainly 204 bp, and they were only $51-55 \%$ identical to each other. Overall, the recovered sequences had only $42-53 \%$ similarity to the reference genes of $S$. trutta and $S$. alpinus (Table 5) that were expected to be in the sediment from lake ZF19. The recovered sequences did not match any published nucleotide references at NCBI, but some regions of the DNA sequences could be identified as plant (Medicago) and bacteria DNA (uncultured environmental bacterium clone) at similarity of 79.3 and $84 \%$, respectively (Table 4). The joint plant and bacteria DNA in the sequences might indicate that the amplified DNA fragments were recombinant DNA resulting from bacterial transformation.

Table 5

Similarity (\%) between recovered sequences from sample ZF19-2 and S. trutta and S. alpinus DNA that were expected to be in the study lakes.

\begin{tabular}{|lllllllllll|}
\hline & Seq1 & Seq2 & Seq3 & Seq4 & Seq5* & Seq7 & Seq8 & Seq14 & Seq15 & Seq16 \\
\hline S. trutta & 44.44 & 44.44 & 44.44 & 44.44 & 44.44 & 44.44 & 51.47 & 44.44 & 42.86 & 44.44 \\
\hline S. alpinus & 50.79 & 50.79 & 50.79 & 50.79 & 50.79 & 50.79 & 52.94 & 50.79 & 49.21 & 50.79 \\
\hline$*$ Seq6, 9, 10, 11, 12, 17, 18, 19 and 20 are identical to Seq5; ${ }^{\dagger}$ Seq8 and Seq11 are identical. & \\
\hline
\end{tabular}

\section{Discussion}

\subsection{Extraction of Fish sed-eDNA using PowerSoil Kit}

One of the challenges in aquatic ecology is to be able to track changes in fish dynamics over timescales extending beyond current monitoring programs, which span a few years up to in a limited number of cases several decades 26,27 . Sed-eDNA has the potential to identify biodiversity changes in response to lake trophic status changes over the past 100 years ${ }^{28}$, and might allow study of historical fish dynamics if sufficient DNA can be recovered as presented by Kuwae et al. ${ }^{6}$.

Our results from the test samples show that the DNA extraction efficiency of the lysis buffer in the PowerSoil Kit, as compared to homemade lysis buffers, was more susceptible to sediment organic content and less DNA could be extracted from the test sediments with higher organic contents. This result agrees with that in Lever et al. ${ }^{11}$ and suggests that the extraction efficiency of the PowerSoil Kit to recover fish sed-eDNA can be impeded in some difficult sample matrices (i.e., organic-rich sediment). It should be noted that the quality of extracted sed-eDNA using the PowerSoil Kit is superior to other kits ${ }^{12}$, and that ancient sed-eDNA from plant and fungi have been successfully extracted from boreal and arctic lake sediments using the PowerSoil/PowerMax $\mathrm{Kit}^{3,13,29}$. Thus, we suggest that the recovery of relatively rare fish sed-eDNA using the PowerSoil Kit is the specific challenge. 
Slon et al. ${ }^{30}$ found that the PowerMax Kit (similar chemistry as PowerSoil Kit) had a poorer ability to recover ultra-short DNA (aDNA is expected to be fairly short, i.e., < 200 bp) from clay in comparison to sodium phosphate buffer and EDTA [supplementary materials in Slon et al. ${ }^{30}$ ]. Some methods have been developed particularly to extract DNA from humus-rich soils and sediments ${ }^{11,24,31,32}$ and they might offer a better means for fish sed-eDNA recovery in the future.

Though the teleo primers might not actually amplify fish DNA in our surface sediments, the ddPCR fish $_{\text {DNA }}$ counts with teleo primers from surface sediment were not correlated to current fish abundance or water chemistry in lakes, but to some extent the counts were correlated to sediment geochemistry $\left(\log _{10} \mathrm{ddPCR}\right.$ fishDNA and LOI: $r=0.329, p<0.01 ; \log _{10}$ ddPCR fish DNA and $\log _{10}$ Fe: $r=-0.525, p<0.01$ ) (Fig. S2). Thus, the fish DNA recovery from sediment might be affected by the geochemical properties of sediments as Kanbar et

al. ${ }^{10}$ suggested geochemical properties of sediments have impacts on DNA adsorption. A better understanding of relationships between sediment properties and DNA recovery will also hugely aid the search for fish sedeDNA.

\subsection{Fish DNA metabarcoding}

The teleo primer pair [called Tele01 in Taberlet et al. ${ }^{33}$ ] are the most promising short metabarcode for teleost fishes with good taxonomic resolution, which was tested empirically on environmental water samples from many aquatic environments ${ }^{14,34}$. However, with the teleo primer pair we only recovered unidentified DNA (partially containing DNA sequences of plant and bacteria) from the sample (ZF19-2) that had the highest DNA count detected by ddPCR. The recombinant DNA containing plant and bacterial DNA was presumably the result of bacterial transformation of short and degraded DNA fragments [described in Pedersen et al. ${ }^{8}$ ] in the lake, showing that bacterial processes in some lakes may impact the survival of extracellular DNA ${ }^{35}$, which brings challenges to sedimentary DNA metabarcoding. Based on this, the very high DNA counts in the ZF19-2 and ZF09 samples are likely ascribed to bacterial transformation followed by bacterial genome replication.

Other universal fish DNA metabarcodes, such as MiFish ${ }^{36}$ and tele02 ${ }^{33}$, have been used recently for the ecological survey of fish DNA in the water column ${ }^{2,37-39}$, but these target DNA fragments of 167-171 bp and therefore might not be suitable for studies of ancient fish sed-eDNA in sediments. SeaDNA-short and SeaDNAmid are more recently-developed metabarcodes targeting the COI gene of fish DNA and the expected fragments are 55 and $130 \mathrm{bp}$, but these metabarcodes perform poorly in comparison to the MiFish barcodes at low template concentrations, and much fewer species were detected in environmental water samples ${ }^{34}$. In general, the MiFish metabarcodes that target $12 \mathrm{~S}$ genes offer high specificity for taxonomic survey, but the lack of adequate references would lead to taxonomic biases ${ }^{34}$. Metabarcoding often introduces taxonomic PCR bias that some species are over-represented and false amplification of unwanted genes, as a result, to use speciesspecific fish primers ${ }^{6,40-42}$ on fish DNA analysis may be a better alternative to avoid the PCR bias that metabarcodes hold.

\section{3 eDNA detection by ddPCR}

Clinical trials have shown that ddPCR assay is a more sensitive approach than qPCR to detect receptor mutations of tumors and to detect viral DNA at very low concentration ${ }^{43,44}$. Further, ddPCR bypasses PCR 
inhibitors in environmental samples and allows absolute eDNA quantification at extremely low concentration ${ }^{20,45}$. Our results also showed that ddPCR possesses a better amplification probability as compared to conventional PCR for difficult environmental samples with PCR inhibitions. However, in many of our samples, the positive detection of target genes at very low quantity could not be verified via sequencing and therefore species identification/confirmation was not possible. Therefore, even with primers or probes that have been empirically tested, using ddPCR to detect fish eDNA at low concentrations might be limited because downstream sequencing for taxonomic confirmation is not viable.

Using species-specific primers for ddPCR assays might solve the issues with PCR bias and false amplification and therefore downstream sequencing might not be necessary. However, the ddPCR quantification uncertainty at extremely low and high concentrations is increased, and thus, accurate DNA quantification requires more PCR replicates (at least 5) ${ }^{46}$. Besides, the false positive rate of ddPCR assays is often inflated ${ }^{46}$ and the data should be carefully scrutinized and interpreted. However, such precautionary measures were not considered in recent studies that applied ddPCR assays on fish eDNA analysis.

Even though the amplified DNA fragments in our samples were unidentified, the high variability in DNA counts in the triplicate surface sediment samples suggest that the spatial distribution of the amplified DNA is heterogeneous. Dommain et al. ${ }^{47}$ showed higher total DNA recovery from older samples in some sediment cores, suggesting local environmental conditions or variability in DNA taphonomy, could result in variations in DNA detection in sediments and this requires further study. Although not studied in detail here (i.e., multiple sites within a lake basin), this would suggest that interpretations of eDNA or aDNA data from only one sediment location may need to be treated cautiously in regard to estimates of fish diversity and abundance. Other studies have also recommended to perform multiple repeats to increase the detection probability of rare species $^{16,48}$.

\section{Conclusions}

In this study we found that the lysis buffer in the PowerSoil DNA Kit was less effective to extract DNA from organic-rich sediments, in comparison to other homemade lysis buffers. The ddPCR assays were more sensitive than conventional PCR for the amplification of DNA with the teleo primers in our 13 sub-alpine/alpine lake (with 24 sampling locations). With the teleo primers, the high number of DNA copies amplified in one sample were unidentified DNA (presumably recombinant DNA) but not fish, and it was impossible to verify the fish DNA amplification in other samples of which very low number of fish DNA copies was counted by ddPCR. It is challenging to search for preserved fish sed-eDNA in lake sediments, presumably due to the inefficient fish DNA recovery from organic-rich sediments or primer performance. For future study we suggest that: (1) better DNA extraction allowing recovery of sufficient and short DNA is required; (2) species-specific fish primers would be better alternatives than metabarcodes to avoid potential false DNA amplification; and (3) the performance of ddPCR to detect eDNA at low quantity needs to be further scrutinized in order to circumvent the pitfalls of false positive.

\section{Declarations}

\section{Declarations}


The teleo primers are patented and this patent only restricts commercial applications and has no impact on the use of this method by academic researchers.

\section{AUTHOR CONTRIBUTIONS}

The study was planned by D.Y.-T.H., R.B., C.B., S.N., J.K. and X.-R.W. S.N primarily led the sediment sampling in Jämtland, and the sediment geochemistry analysis as well as interpretation were performed by both R.B. and S.N. The molecular experiments and exposition were performed by D.Y.-T.H., F.O. and X.-R.W. Data were analyzed and processed by D.Y.T.H. and D.C.P.L.; manuscript writing was led by D.Y.-T.H. and finalized by all authors.

\section{ACKNOWLEDGEMENTS}

This study is funded by Knut and Alice Wallenberg Foundation Project Funding (d.nr. 2016.0083) awarded to Professor Jan Karlsson in Department of Ecology and Environmental Science at Umeå University, Sweden. We thank Dr. Eric Capo for the sampling coordination and thank the Biogeochemical Analytical Facility and the a/eDNA Lab at Umeå University. We also acknowledge Sven Norman for the collection of water samples, fish survey and water chemistry data collection from the country boards, and we thank Dr. Anders Jonsson for water nutrient analyses.

\section{References}

1. 1. Turner, C. R., Uy, K. L. \& Everhart, R. C. Fish environmental DNA is more concentrated in aquatic sediments than surface water. Biological Conservation 183, 93-102 (2015).

2. 2. Sales, N. G. et al. Space-time dynamics in monitoring neotropical fish communities using eDNA metabarcoding. Sci Total Environ 754, 142096 (2021).

3. 3. Talas, L., Stivrins, N., Veski, S., Tedersoo, L. \& Kisand, V. Sedimentary Ancient DNA (sedaDNA) Reveals Fungal Diversity and Environmental Drivers of Community Changes throughout the Holocene in the Present Boreal Lake Lielais Svetinu (Eastern Latvia). Microorganisms 9, 719 (2021).

4. 4. Olajos, F. et al. Estimating species colonization dates using DNA in lake sediment. Methods in Ecology and Evolution 9, 535-543 (2018).

5. 5. Nelson-Chorney, H. T. et al. Environmental DNA in lake sediment reveals biogeography of native genetic diversity. Frontiers in Ecology and the Environment 17, 313-318 (2019).

6. 6. Kuwae, M. et al. Sedimentary DNA tracks decadal-centennial changes in fish abundance. Commun Biol 3, 558 (2020).

7. 7. Rawlence, N. J. et al. Using palaeoenvironmental DNA to reconstruct past environments: progress and prospects. Journal of Quaternary Science 29, 610-626 (2014).

8. 8. Pedersen, M. W. et al. Ancient and modern environmental DNA. Philosophical transactions of the Royal Society of London. Series B, Biological sciences 370, 20130383 (2015). 
9. 9. Zeale, M. R., Butlin, R. K., Barker, G. L., Lees, D. C. \& Jones, G. Taxon-specific PCR for DNA barcoding arthropod prey in bat faeces. Mol Ecol Resour 11, 236-244 (2011).

10. 10. Kanbar, H. J., Olajos, F., Englund, G. \& Holmboe, M. Geochemical identification of potential DNAhotspots and DNA-infrared fingerprints in lake sediments. Applied Geochemistry 122, 104728 (2020).

11. 11. Lever, M. A. et al. A modular method for the extraction of DNA and RNA, and the separation of DNA pools from diverse environmental sample types. Frontiers in microbiology 6, 476 (2015).

12. 12. Pearman, J. K. et al. Comparing sediment DNA extraction methods for assessing organic enrichment associated with marine aquaculture. PeerJ 8, e10231 (2020).

13. 13. Niemeyer, B., Epp, L. S., Stoof-Leichsenring, K. R., Pestryakova, L. A. \& Herzschuh, U. A comparison of sedimentary DNA and pollen from lake sediments in recording vegetation composition at the Siberian treeline. Mol Ecol Resour 17, e67-e62 (2017).

14. 14. Valentini, A. et al. Next-generation monitoring of aquatic biodiversity using environmental DNA metabarcoding. Molecular ecology 25, 929-942 (2016).

15. 15. Sard, N. M. et al. Comparison of fish detections, community diversity, and relative abundance using environmental DNA metabarcoding and traditional gears. Environmental DNA 1, 368-384 (2019).

16. 16. Shaw, J. L. A. et al. Comparison of environmental DNA metabarcoding and conventional fish survey methods in a river system. Biological Conservation 197, 131-138 (2016).

17. 17. Prosser, S., Martinez-Arce, A. \& Elias-Gutierrez, M. A new set of primers for COI amplification from freshwater microcrustaceans. Mol Ecol Resour 13, 1151-1155 (2013).

18. 18. Capo, E., Spong, G., Königsson, H. \& Byström, P. Effects of filtration methods and water volume on the quantification of brown trout (Salmo trutta) and Arctic char (Salvelinus alpinus) eDNA concentrations via droplet digital PCR. Environmental DNA 2, 152-160 (2020).

19. 19. Doi, H. et al. Droplet digital polymerase chain reaction (PCR) outperforms real-time PCR in the detection of environmental DNA from an invasive fish species. Environmental Science \& Technology 49, 5601-5608 (2015).

20. 20. Doi, H. et al. Use of droplet digital PCR for estimation of fish abundance and biomass in environmental DNA surveys. PLoS One 10, e0122763 (2015).

21. 21. Nathan, L. M., Simmons, M., Wegleitner, B. J., Jerde, C. L. \& Mahon, A. R. Quantifying environmental DNA signals for aquatic invasive species across multiple detection platforms. Environmental Science \& Technology 48, 12800-12806 (2014).

22. 22. Capo, E. et al. Droplet digital PCR assays for the quantification of brown trout (Salmo trutta) and Arctic char (Salvelinus alpinus) from environmental DNA collected in the water of mountain lakes. PLoS One 14, e0226638 (2019).

23. 23. Rydberg, J. Wavelength dispersive X-ray fluorescence spectroscopy as a fast, non-destructive and costeffective analytical method for determining the geochemical composition of small loose-powder sediment samples. Journal of Paleolimnology 52, 265-276 (2014).

24. 24. Huang, Y.-T. et al. A new method to extract and purify DNA from allophanic soils and paleosols, and potential for paleoenvironmental reconstruction and other applications. Geoderma 274, 114-125 (2016). 
25. 25. Meyer-Jacob, C. et al. Independent measurement of biogenic silica in sediments by FTIR spectroscopy and PLS regression. Journal of Paleolimnology 52, 245-255 (2014).

26. 26. Winder, M. \& Schindler, D. E. Climcate change uncouples trophic interactions in an aquatic ecosystem. Ecology 85, 2100-2106 (2004).

27. 27. Dodds, W. K. et al. Surprises and Insights from Long-Term Aquatic Data Sets and Experiments. BioScience 62, 709-721 (2012).

28. 28. Domaizon, I. et al. DNA from lake sediments reveals the long-term dynamics and diversity of Synechococcus assemblages. Biogeosciences 10, 3817-3838 (2013).

29. 29. Alsos, I. G. et al. Plant DNA metabarcoding of lake sediments: How does it represent the contemporary vegetation. PLoS One 13, e0195403 (2018).

30. 30. Slon, V. et al. Neandertal and Denisovan DNA from Pleistocene sediments. Science 356, 605-608 (2017).

31. 31. Miao, T. et al. A method suitable for DNA extraction from humus-rich soils. Biotechnology Letters 36, 2223-2228 (2014).

32. 32. Dong, D., Yan, A., Liu, H., Zhang, X. \& Xu, Y. Removal of humic substances from soil DNA using aluminium sulfate. Journal of Microbiological Methods 66, 217-222 (2006).

33. 33. Taberlet, P., Bonin, A., ZInger, L. \& COissac, E. Environmental DNA: For Biodiversity Research and Monitoring. (Oxford University Press, 2018).

34. 34. Collins, R. A. et al. Non-specific amplification compromises environmental DNA metabarcoding with COI. Methods in Ecology and Evolution 10, 1985-2001 (2019).

35. 35. Ellegaard, M. et al. Dead or alive: sediment DNA archives as tools for tracking aquatic evolution and adaptation. Communications Biology 3, 169 (2020).

36. 36. Miya, M. et al. MiFish, a set of universal PCR primers for metabarcoding environmental DNA from fishes: detection of more than 230 subtropical marine species. Royal Society open science 2, 150088 (2015).

37. 37. Kume, M. et al. Factors structuring estuarine and coastal fish communities across Japan using environmental DNA metabarcoding. Ecological Indicators 121, 107216 (2021).

38. 38. Chen, J. et al. Revealing an Invasion Risk of Fish Species in Qingdao Underwater World by Environmental DNA Metabarcoding. Journal of Ocean University of China 20, 124-136 (2021).

39. 39. Russo, T. et al. All is fish that comes to the net: metabarcoding for rapid fisheries catch assessment. Ecological Applications 31, e02273 (2021).

40. 40. Troth, C. R. et al. Development and application of eDNA-based tools for the conservation of whiteclawed crayfish. Sci Total Environ 748, 141394 (2020).

41. 41. Penaluna, B. E. et al. Better boundaries: identifying the upper extent of fish distributions in forested streams using eDNA and electrofishing. Ecosphere 12, e03332 (2021).

42. 42. Nevers, M. B. et al. Influence of sediment and stream transport on detecting a source of environmental DNA. PLoS One 15, e0244086, doi:10.1371/journal.pone.0244086 (2020).

43. 43. Suo, T. et al. ddPCR: a more accurate tool for SARS-CoV-2 detection in low viral load specimens. Emerg Microbes Infect 9, 1259-1268 (2020). 
44. 44. Wang, W., Song, Z. \& Zhang, Y. A Comparison of ddPCR and ARMS for detecting EGFR T790M status in ctDNA from advanced NSCLC patients with acquired EGFR-TKI resistance. Cancer Med 6, 154-162 (2017).

45. 45. Capo, E. et al. Droplet digital PCR applied to environmental DNA, a promising method to estimate fish population abundance from humic-rich aquatic ecosystems. Environmental DNA 3, 343-352 (2020).

46. 46. Vynck, M., Vandesompele, J. \& Thas, O. Quality control of digital PCR assays and platforms. Analytical and bioanalytical chemistry 409, 5919-5931 (2017).

47. 47. Dommain, R. et al. The Challenges of Reconstructing Tropical Biodiversity With Sedimentary Ancient DNA: A 2200-Year-Long Metagenomic Record From Bwindi Impenetrable Forest, Uganda. Frontiers in Ecology and Evolution 8, 218 (2020).

48. 48. Sjogren, P. et al. Lake sedimentary DNA accurately records 20 (th) Century introductions of exotic conifers in Scotland. The New phytologist 213, 929-941 (2017).

49. DATA AVAILABILITY

50. All the sequence data are available.

\section{Tables}

Due to technical limitations, Table 4 is only available as a download in the Supplemental Files section.

\section{Figures}

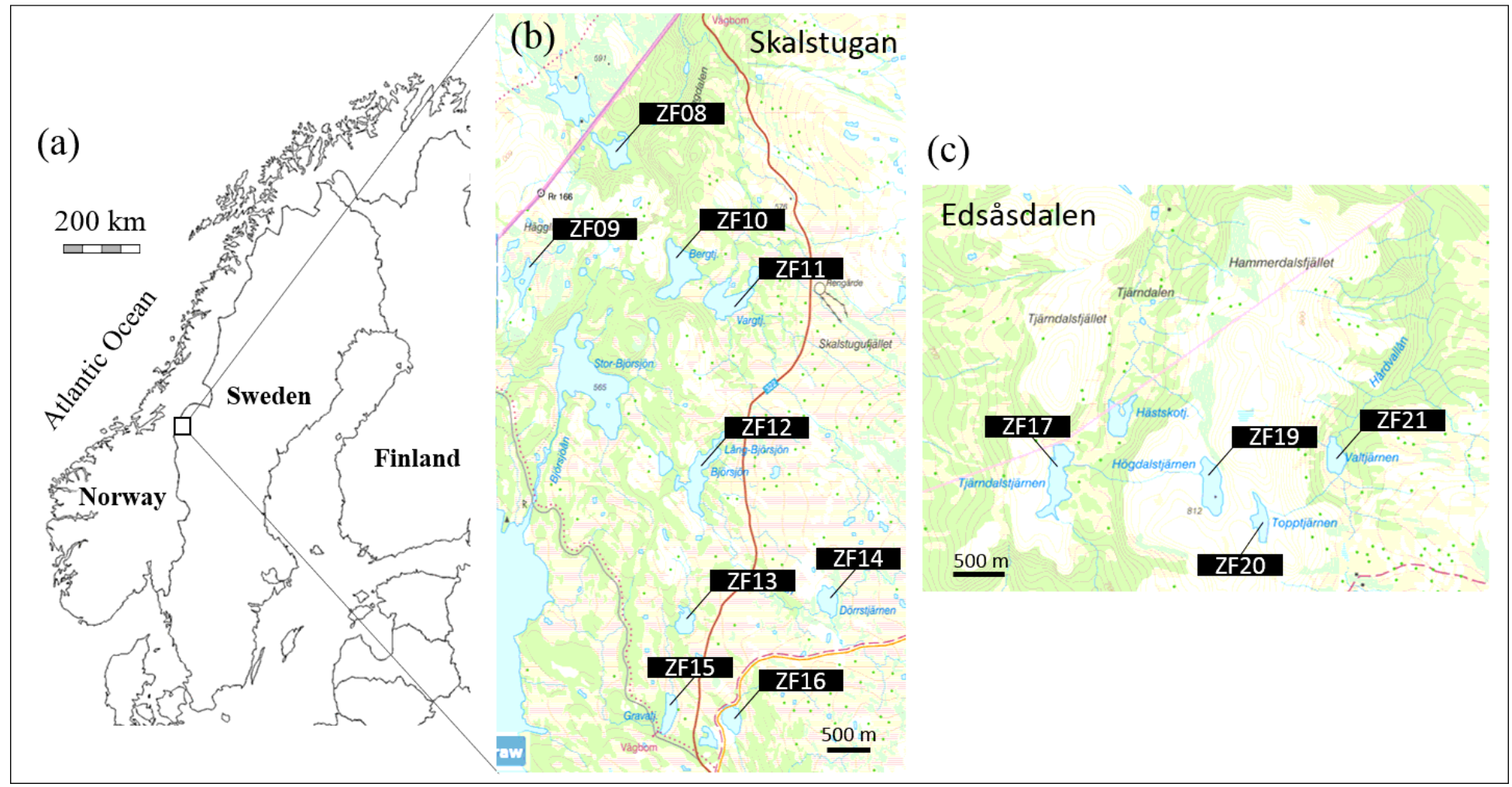

Figure 1 
Map of Jämtland in Sweden (a) and digital maps of study lakes (b and c) acquired from Lantmäteriet using the Geodata Extraction Tool developed by The Swedish University of Agricultural Sciences (maps.slu.se).
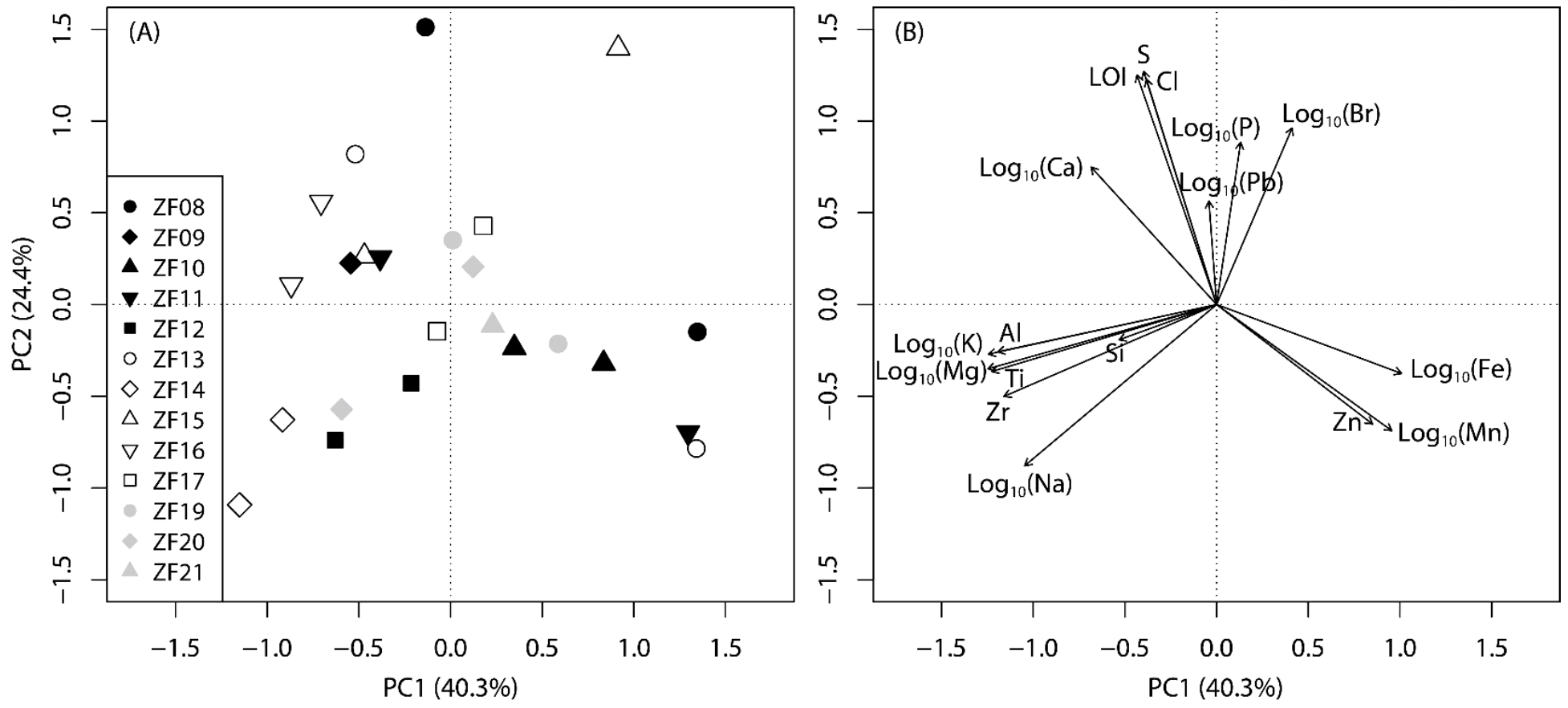

Figure 2

Variation in surface sediment composition presented in a two dimensional space with principal component scores for deep and shallow sites (A) and variable loadings (B) for the first (PC1) and second (PC2) principal components. PC1 separates samples characterized by redox sensitive elements (Fe, Mn and $\mathrm{Zn}$ ) and silicate minerals ( $\mathrm{Al}, \mathrm{K}, \mathrm{Mg}, \mathrm{Na}, \mathrm{Ti}$ and $\mathrm{Zr}$ ), and PC2 highly organic samples ( $\mathrm{LOI}, \mathrm{Br}, \mathrm{Ca}, \mathrm{Cl}, \mathrm{P}, \mathrm{Pb}$ and $\mathrm{S}$ ) from less organic samples. Silicon is partly related to silicate minerals on PC1 but is primarily of biogenic origin and therefore loads on a separate component (PC3, not shown). 


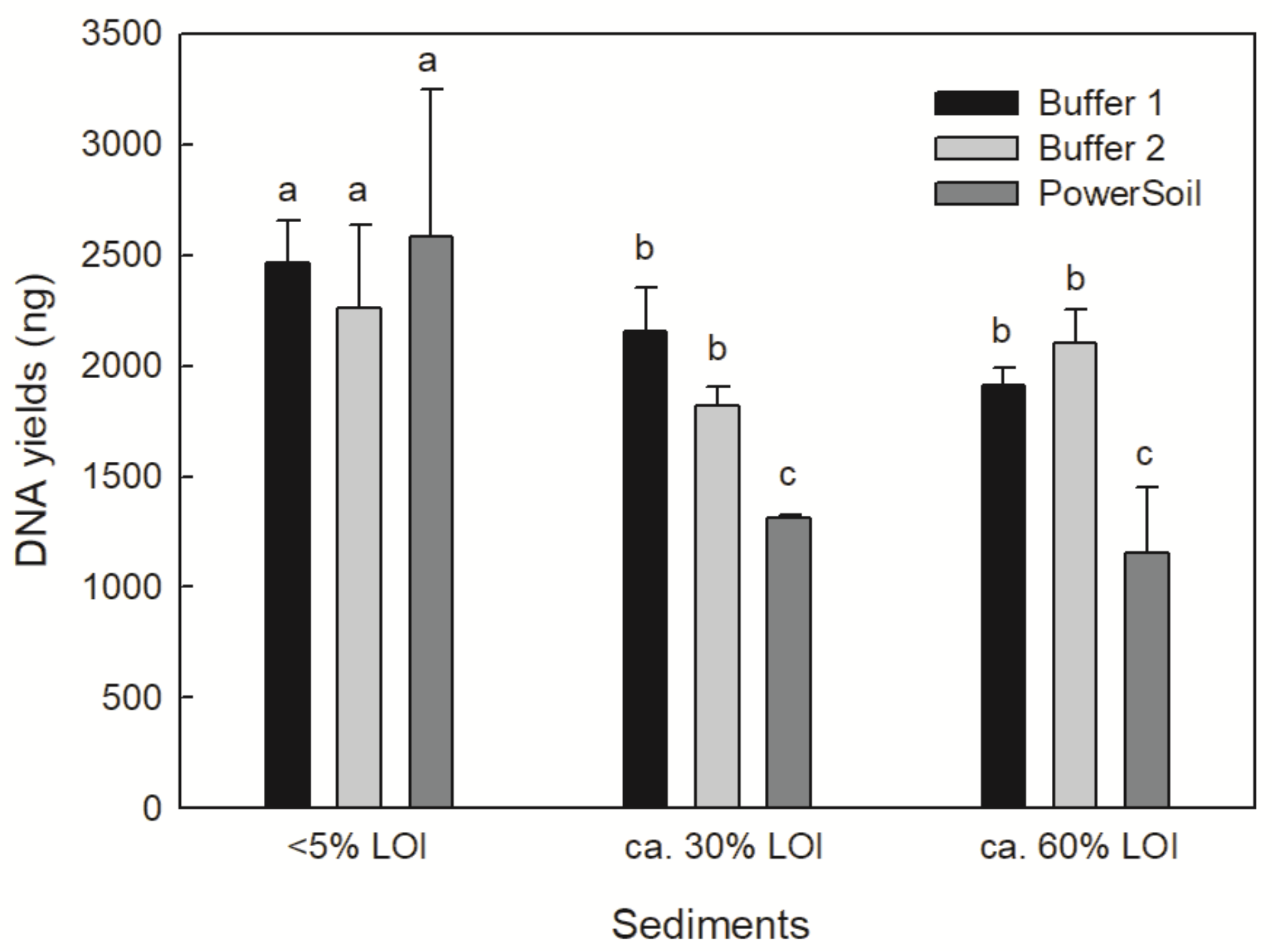

Figure 3

Comparisons of DNA yields (before purification steps) from sediments with varying organic contents (i.e. LOI) by using different extraction buffers. Buffer 1 contains 1\% SDS, 100mM Tris-HCl, $200 \mathrm{mM}$ EDTA, and $500 \mathrm{mM}$ Na2HPO4 (pH 8.6); Buffer 2 contains 4\% SDS, 100 mM Tris-HCl, 200 mM EDTA, and 500 mM Na2HPO4; Buffer 3 contains $30 \mathrm{mM}$ Tris-HCl, $30 \mathrm{mM}$ EDTA, $800 \mathrm{mM}$ quanidium hydrochloride, and 0.5\% Triton X-100; Buffer from PowerSoil Kit was the $\mathrm{C} 1$ solution (lysis buffer) with the buffer in bead tube. No DNA was recovered from Buffer 3 thus the data was not shown here to simply the figure. Bars with different letters $(a, b$ and $c)$ are significantly different $(p=0.001)$ based on two-way ANOVA and Tukey HSD post-hoc comparisons.

\section{Supplementary Files}

This is a list of supplementary files associated with this preprint. Click to download.

- Table4.docx

- Huangetal.SupplementaryMaterials.docx 